\title{
SCLEROSING STROMAL CELL TUMOR OF THE OVARY IN PREGNANCY: A CASE REPORT AND REVIEW OF THE LITERATURE
}

\author{
Il Dong Kim, MD, Ho Sun Chang, MD, Kyung Jin Hwang, MD \\ Department of Obstetrics and Gynecology, Grace Women's Hospital, Goyang, Korea
}

A sclerosing stromal tumor of the ovary is an extremely rare benign tumor in pregnant women. Only 9 reports of sclerosing stromal tumor of the ovary during pregnancy have been presented. A 26-year-old woman at the 10th week of gestation was explored via laparoscopic surgery. She had non-specific symptoms but high levels of the tumor marker. The pathological diagnosis was sclerosing stromal tumor of the right ovary. We report a case of sclerosing stromal tumor in a 26-year-old woman who was admitted to confirm pregnancy with a review of the literature.

Keywords: Sclerosing stromal tumor; Pregnancy; Ovarian neoplasm

A sclerosing stromal tumor (SST) of the ovary is an extremely rare sex cord-stromal tumor. This tumor occurs predominantly in young females at an average age of 27 to 28 years old [1]. Since it was first described by Chavarjian and Scully in 1973, fewer than 100 cases have been described in the literature [2]. Moreover, a few cases of SST in pregnant women have been described [3-5].

SST should be distinguished from malignant tumors, but it is difficult to diagnose before surgery by imaging studies. It used to be diagnosed by pathological examination during surgery or after surgery. We report the ultrasonographic and histological findings of a SST of the right ovary during pregnancy with review of the literature.

\section{Case Report}

A 26-year-old woman presented to the hospital with nausea and amenorrhea that was reported to have started about 3 weeks ago. The patient did not have regular cytologic smears and pelvic ultrasonographic examination. Transvaginal ultrasound showed a single fetus was present in the uterine cavity and the size was 8th week. A $6.5 \times 5.3 \mathrm{~cm}$ mass was demonstrated, lateral and posterior to the uterus, and was homogeneously hypoechoic (Fig. 1A). Power Doppler gave slow low-flow vascular signals. Also, the se- rum CA-125 level was high (96.72 Ul/mL). There was no unusual symptoms such as pelvic pain, hypermenorrhea, and menstrual irregularities, due to SST.

When 10 weeks of gestation, surgery was performed because the pregnant women worried about tumor effects on the fetus. A right oophorectomy was performed. Under general anaesthesia, laparoscopy showed a normal uterus and left ovary with the right ovary replaced by a solid mass. On gross inspection, the removed right ovarian mass measured $7 \times 5 \times 6 \mathrm{~cm}$ and weighed $154 \mathrm{~g}$. The mass was gray-white in color and had a smooth and well-encapsulated surface (Fig. 1B). The cut surface was a focally pale yellow solid and cystic fragment. The frozen section was not performed

Received: 2011.10.19. Revised: 2012.2.1. Accepted: 2012.3.9.

Corresponding author: Il Dong Kim, MD

Department of Obstetrics and Gynecology, Grace Women's

Hospital, 1073 Jungang-ro, Ilsandong-gu, Goyang 410-360, Korea

Tel: +82-31-901-4000 Fax: +82-31-907-1717

E-mail:kimid@hanmail.net

This is an Open Access article distributed under the terms of the Creative Commons Attribution Non-Commercial License (http://creativecommons.org/licenses/ by-nc/3.0/) which permits unrestricted non-commercial use, distribution, and reproduction in any medium, provided the original work is properly cited.

Copyright (๑) 2012. Korean Society of Obstetrics and Gynecology 


\title{
KOREAN JOURNAL OF OBSTETRICS \& GYNECOLOGY
}

\author{
KJOG Vol. 55, No. 4, 2012
}
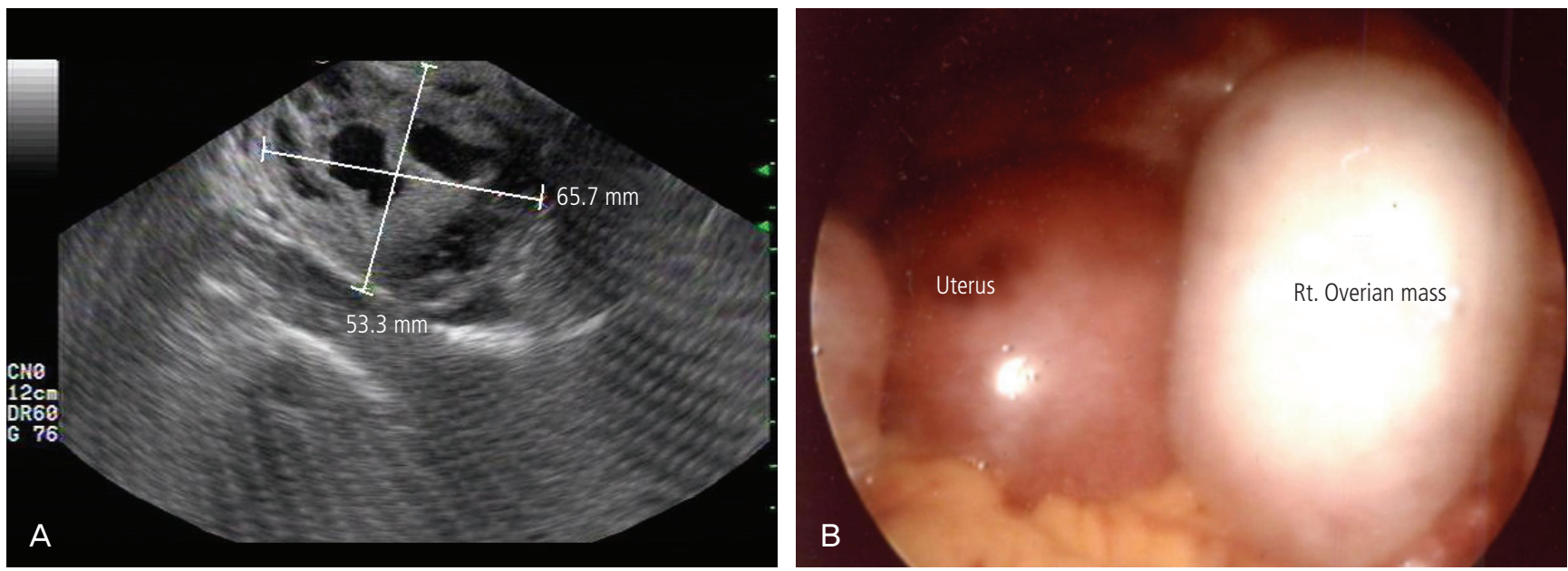

Fig. 1. (A) Ultrasonography disclosed a large round mass, mainly solid and with small central hypoechoic and anechoic areas, in the right adnexal region. (B) Laparoscopic finding of the tumor reveals that it is gray-white in color and has a smooth and well-encapsulated surface.
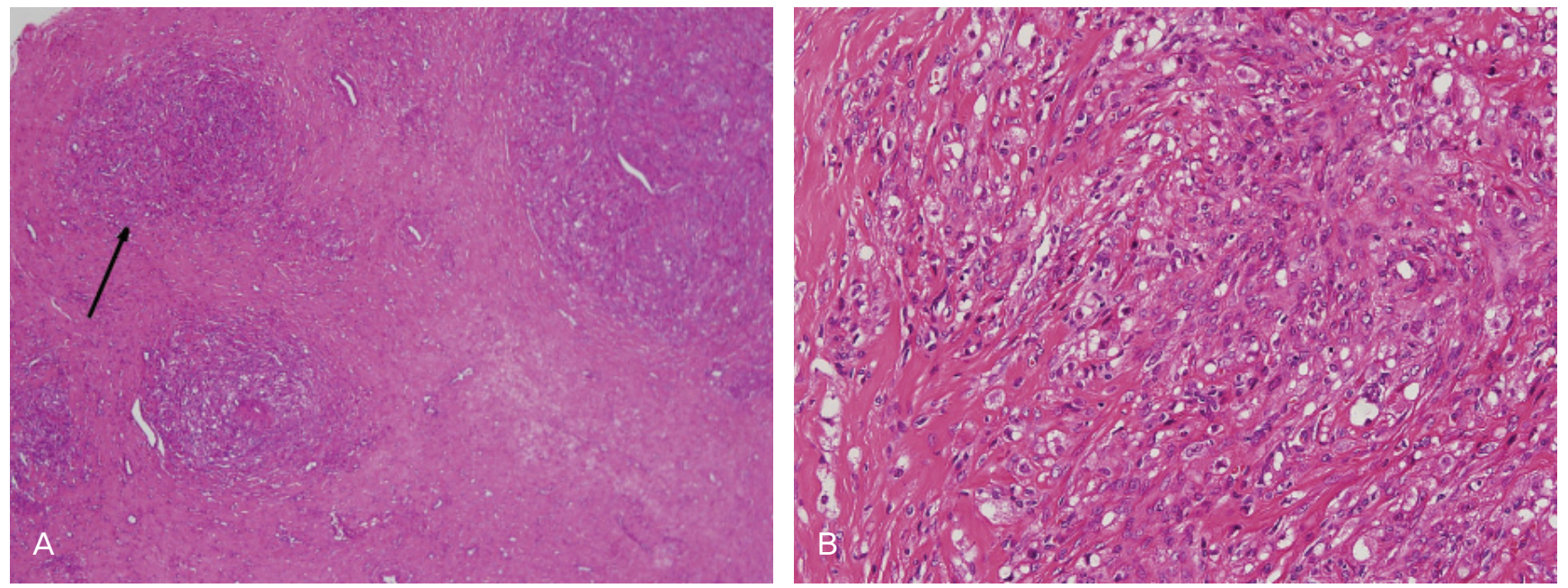

Fig. 2. (A) Histological appearance showing the pseudolobular pattern consisting of a hypercellular (arrow) and hypocellular area (H\&E, $\times 40)$. (B) Histological appearance showing the vasculated and spindled fibroblast-like cells $(H \& E, \times 400)$.

because pathology is not here. In microscopic findings there was an irregularly mixed pattern with hypercellularity and hypocellularity areas. Hypercellularity areas showed a pseudolobular structure, whereas hypocellularity areas showed an edematous structure (Fig. 2A). Hypocellularity and hypercellularity areas were divided by a hyalinized connective tissue. Many blood vessels were distributed in the boundary region. Polyhedral and spindle-shaped cells were mixed in the hypercellularity areas (Fig. 2B). The pathological diagnosis was SST of the right ovary. After surgery, the CA-125 level returned to normal. Pregnancy has been well maintained without any problems.

\section{Discussion}

Sclerosing stromal tumor is a rare benign ovarian tumor originating from granulosa-stromal cell tumor group. SST occurs most frequently in young females (average age at diagnosis 27, to 28 years) [6] and the most common signs and symptoms are a palpable pelvic mass, metrorrhagia, menstural irregularity, and pelvic pain. The histopathology of the SST shows a pseudolobular pattern of cellular areas and hypocellular, edematous or collagenous areas. It has a prominent vasculature and prominent sclerosis around clusters of individual cells as well as cellular heterogeneity of the vacuolated luteinized theca-like cells and spindle shaped fibroblast-like cells in the cellular areas [7]. Immunohistochemically, the cells of 


\section{KOREAN JOURNAL OF OBSTETRICS \& GYNECOLOGY}

II Dong Kim, et al. Sclerosing stromal cell tumor of the ovary in pregnancy

SSTs are positive for vimentin, smooth muscle actin, $\alpha$-inhibin, and CD99; and are negative for S-100 protein and epithelial markers [2]. In early pregnancy, the most common masses are corpus luteum cysts, whereas after the first trimester, benign cystic teratomas and cystadenomas are more frequently observed. Surgery is in most cases performed during pregnancy, since $2 \%$ to $5 \%$ of lesions are malignant, and large benign masses can cause complications during delivery [8]. In the evaluation of a pelvic mass during pregnancy computed tomography should be avoided because of the radiation dose. It may also have a detrimental effect on fetal development in the first trimester. Ultrasonography (US) is useful for distinguishing between cystic and solid masses [9], but can be undetermined in lesion characterization, such that a differential diagnosis from malignant ovarian neoplasms is not always possible [10].

US and computed tomography (CT) findings of SST show an increased peripheral vascular as seen in malignant tumors. Since peripheral is a thick layer with a remarkable proliferation of blood vessels, the stromal is the representing form of lobulation by local edema.

SST can not predict its presence preoperatively on the basis of clinical and ultrasonographic findings alone. Magnetic resonance imaging (MRI) is the technique of choice in the characterization and preoperative assessment of pelvic masses during pregnancy. MRI findings include typical signal patterns such as hypointense nodules, hyperintense stroma, lobulation, strong enhancement with gadolinium and a peripheral hypointense rim are present [11]. Sclerosing stromal tumors were reported in which the inactive tumors did not represent endocrine clinical symptoms [7]. However, currently according to several reports, it is the active tumor that produce hormones [12-14]. A few case of SST in pregnant women have been described about virilization. In this case, neither hormonal activity nor virilization was observed.

Treatment of SST is sufficient only for oophorectomy because these are benign tumors. By considering the impact on pregnancy, progesterone $100 \mathrm{mg}$ was taken vaginally until 12 weeks of gestation. SST is a very rare tumor but tumor markers, hormone tests and US, in addition to MRI should be performed when the women are under the age of 30 and the visual inspection reveals $5 \mathrm{~cm}$ or more of a solid tumor. Frozen biopsies should also be performed during surgery. We report a case of SST in a 26-year-old woman who was admitted to confirm pregnancy with a review of the literature.

\section{References}

1. Fefferman NR, Pinkney LP, Rivera R, Popiolek D, HummelLevine $P$, Cosme J. Sclerosing stromal tumor of the ovary in a premenarchal female. Pediatr Radiol 2003;33:56-8.

2. Chang W, Oiseth SJ, Orentlicher R, Agarwal G, Yahr LJ, Cayten CG. Bilateral sclerosing stromal tumor of the ovaries in a premenarchal girl. Gynecol Oncol 2006;101:342-5.

3. Cashell AW, Cohen ML. Masculinizing sclerosing stromal tumor of the ovary during pregnancy. Gynecol Oncol 1991:43:281-5.

4. Duska LR, Flynn C, Goodman A. Masculinizing sclerosing stromal cell tumor in pregnancy: report of a case and review of the literature. Eur J Gynaecol Oncol 1998;19:441-3.

5. Huang SC, Chen HC, Chang KC, Chou CY. Ascites and elevated androgen level in a pregnant patient with an ovarian sclerosing stromal tumor. J Formos Med Assoc 2003;102:124-6.

6. Ihara N, Togashi K, Todo G, Nakai A, Kojima N, Ishigaki T, et al. Sclerosing stromal tumor of the ovary: MRI. J Comput Assist Tomogr 1999;23:555-7.

7. Chalvardjian A, Scully RE. Sclerosing stromal tumors of the ovary. Cancer 1973;31:664-70.

8. Kier R, McCarthy SM, Scoutt LM, Viscarello RR, Schwartz PE. Pelvic masses in pregnancy: MR imaging. Radiology 1990;176:709-13.

9. Dewbury KC, Meire HB, Cosgrove DO, Farrant P. Ultrasound in obstetrics and gynaecology. 2nd ed. London: Churchill Livingstone; 2001.

10. Joja I, Okuno K, Tsunoda M, Takeda Y, Sugita K, Mizutani Y, et al. Sclerosing stromal tumor of the ovary: US, MR, and dynamic MR findings. J Comput Assist Tomogr 2001;25:201-6.

11. Calabrese M, Zandrino F, Giasotto V, Rissone R, Fulcheri E. Sclerosing stromal tumor of the ovary in pregnancy: clinical, ultrasonography, and magnetic resonance imaging findings. Acta Radiol 2004;45:189-92.

12. Damajanov I, Drobnjak P, Grizelj V, Longhino N. Sclerosing stromal tumor of the ovary: a hormonal and ultrastructural analysis. Obstet Gynecol 1975;45:675-9.

13. Tsukamoto N, Nakamura M, Ishikawa H. Case report: sclerosing stromal tumor of the ovary. Gynecol Oncol 1976;4:335-9.

14. Ho Yuen B, Robertson DI, Clement PB, Mincey EK. Sclerosing stromal tumor of the ovary. Obstet Gynecol 1982;60:252-6. 


\section{KOREAN JOURNAL OF OBSTETRICS \& GYNECOLOGY}

KJOG Vol. 55, No. 4, 2012

임신 중 발견된 난소의 경화성 간질 종양 : 증례보고

그레이스병원 산부인과

김일동, 장호선, 황경진

임신부에서 난소의 경화성 간질종양은 난소에 발생하는 매우 드문 양성 종양으로 9 예만 보고되었다. 26세 임신 10 주에 특징적인 임상 증상 없이 종양 표지자인 CA-125만 증가된 경화성 간질 종양을 경험하였기에 간단한 문헌 고찰과 함께 보고하는 바이다.

중심단어: 경화성 간질 종양, 임신, 난소 종양 